\title{
Rевенсн АвтіскE: Role perception and role performance of the women members of village Grampanchayat
}

\section{J. H. Gaikwad}

Article Chronicle:

Received :

15.02.2020;

Revised:

06.10.2020;

Accepted :

$25 . .10 .2020$

KEY WoRDS :

Role perception,

Role performance,

Women members of

Grapanchayat
SUMMARY : Grampanchayat is the most important basic institution for the development of village. In the present study in all 125 women members were selected by adopting following criteria of $\mathrm{N}^{\text {th }}$ method. Initially, the list of the women members were prepared alphabetically and then from the said list alternate member were selected as respondents. Hence, out of 250 women Grampanchayat members in all 125 were covered under the study. It was observed that more than half (52.00 per cent) of the respondents had medium level of their role perception while 26.00 per cent and 21.60 per cent of them had high and low level of role perception about functioning of Grampanchayat respectively. Nearly half (48.00 per cent) of the respondents had medium level of role performance while 31.20 per cent of them had low level of role performance and 20.80 per cent of them had high level of role performance.

How to cite this article : Gaikwad, J.H. (2020). Role perception and role performance of the women members of village Grampanchayat. Agric. Update, 15(4): 432-434; DOI : 10.15740/HAS/AU/15.4/432-434. Copyright@ 2020: Hind Agri-Horticultural Society.

\section{Author for correspondence :}

\section{J. H. Gaikwad}

Agriculture Technology School, Puntamba, Ahmednagar (M.S.) India Email: jh_gaikwad@ rediffmail.com 